\title{
Multilingualism as utopia
}

\section{Fashioning non-racial selves}

\section{Christopher Stroud \& Quentin Williams}

University of the Western Cape, South Africa / Stockholm University, Sweden

The challenge of contemporary South Africa is that of building a (post)nation of postracial equity in a fragmented world of a globalized ethical, economic and ecological meltdown. In this paper, we seek to explore the idea of multilingualism as a technology in the conceptualization of alternative, competing futures. We suggest that multilingualism is understood in terms of how encounters across difference are mediated and structured linguistically to offer a space for interrupting colonial relationships. Furthermore, we argue that multilingualism should be approached as a site where colonial power dynamics of languages and speakers are troubled, and where the potential for new empowering linguistic mediations of the mutualities of our common humanity with different others are worked out.

Keywords: multilingualism; utopia; non-racialism; Afrikaans; Afrikaaps; South Africa

\section{Introduction}

Postapartheid South Africa inherited a complex, shifting and divisive system of racial classification at democracy in 1994 that continues to seep into the minutia of everyday life of the majority of South Africans. Thus, not surprisingly, one of the major challenges of contemporary South Africa is that of building a (post) nation of postracial equity in a fragmented world of a globalized ethical, economic and ecological meltdown. In Achille Mbembe's words, such a challenge requires of us to:

tease out alternative possibilities for thinking life and human futures in this age of neoliberal individualism, /where/ we need to connect in entirely new ways the project of non-racialism to that of human mutuality.

(Mbembe, 2016)

Language is one of the most fundamental aspects of being human. And multilingualism, although commonly, and broadly, understood as referencing the co-existence and juxtaposition of more than one language, can also be seen as a 
nomenclature for how the practice and representation of encounters across difference is organized linguistically. Thus, a reasonable assumption is that multilingualism ought to provide a site par excellence for the nurturing of new forms of human mutuality. However constructs of multilingualism have been important tools of colonial governmentality, ${ }^{1}$ comprising technologies, among others, for ordering social indexicalities of language into labelled and hierarchical systems of speakerhood (first/second language speaker of X; native/foreigner, semilingual, etc); arranging languages within different 'orders of visibility' (as recognized, prohibited, surveilled, monitored) (cf. Kerfoot \& Hyltentam, 2017); as well as attributing functional and temporal differentiation to them (e.g. African languages are of the past and future, metropolitan languages live and thrive in ever-present, messianic time) (cf. Stroud \& Guissemo, 2015). In these ways, multilingualism has predominantly served to silence, invisibilize, and sort speakers and languages hierarchically. It has comprised a site for 'othering' and, in colonial contexts, including the South African, the 'othering' has invariably been racialized. Thus, although ostensibly promising a trope for linguistic (and cultural) diversity, multilingualism shoud also be understood, in common with other forms of neoliberal technology, as a mechanism whereby essential features of colonial social logics are reconfigured in contemporary 'postcolonial' societies (Stroud \& Guissemmo, 2015). In this sense, multilingualism is a response to "the effects of anti and postcolonial movements in the liberal world" by "allow/ing/ cultures a space within liberalism without rupturing the core frameworks of figuring experience" (Povinelli, 2011). As such, the construct is hardly likely to benefit a search for a rejuvenated human mutuality.

However, we suggest here that multilingualism understood in terms of how encounters across difference are mediated and structured linguistically, can also offer a space for interrupting colonial relationships, in pursuit of the 'human mutuality' that Mbembe refers to. In this paper, we explore precisely multilingualism as a site where colonial power dynamics of languages and speakers are troubled, and where the potential for new empowering linguistic mediations of the mutualities of our common humanity with different others are worked out. More specifically, we explore ways in which multilingualism offers an as yet untapped potential for connecting the project of human mutuality to that of non-racialism, and the imagining of "alternative possibilities for thinking life and human futures".

1. In propounding this critical stance on multingualism, we are nevertheless aware that it is precisely such a concept that has allowed (linguistic) minorities to argue for right to their languages and cultures in a move of 'strategic essentialism' in a liberal politics of recognition. 
We structure the paper in two steps around two case studies. We begin by exploring aspects of the conventional understandings of multilingualism in the replication of colonial/apartheid notions of race in contemporary South Africa. We do this in relation to a particular language in that construct, Afrikaans, and discuss the complex ways through which the place of Afrikaans in a local multilingual regime reproduces apartheid "frameworks of figuring experience" (Povinelli, 2011).

The second part of the paper discusses a different construal of multilingualism and a different construct of Afrikaans. These construals emerge out of a set of counter discourses and out of the unraveling of Afrikaans as an officially designated language. These processes illustrate the possibilities of a different and rethought construct of multilingualism. We introduce here a notion of 'utopian surplus' (e.g. Anderson, 2002) and suggest that multilingualism can offer a blueprint from which to pursue the enjoyment of 'human mutuality'.

The data for each case study comprise documentaries, one of which depicts a protest and the other a performance. The protest documented took place at Stellenbosch University, one of the premier universities in South Africa, and one of the few historically Afrikaans medium institutions. The documentary captures the voices of the students in the Open Stellenbosch movement, as they tell of their problems with being black in Stellenbosch, and the role of Afrikaans in the everyday racialization of their lives. The second documentary follows the production of a Hiphopera celebrating the recapturing of Afrikaans, and its rebirth as Afrikaaps. Both protest and performance are 'acts of citizenship' (Isin, 2009) where claims to rights (or rights violations) are made on a variety of scenes and scales.

\section{Race and multilingualism in South Africa: The Luister (Listen) documentary}

In 1990, winds of change blew open the gates of Stellenbosch University (SU), to admit African language speakers. Stellenbosch University ranks second on university listings in South Africa after the University of Cape Town, and can boast the dubious merit of having produced the economic and political elite of apartheid South Africa. Up until then, it had been an exclusively Afrikaans speaking establishment, Afrikaans together with English having comprised the only two official languages in the country. On the heels of South Africa's transition to democracy, constitutional recognition was granted to 11 official languages, together with a broad sweep of structural reform that included: Chapter nine institutions, the Pan South African Language Board, and various bills such as the Protection of 
Religious, Sexual and Linguistic Minorities Act. Provisions and services - albeit insufficient - were established for education and medical services in the form of offerings of different reach for mother tongue/bilingual content teaching (education) or translation services (medical). More recently, the South African Broadcasting Corporation increased its broadcasts in local language materials, stipulating that a minimum of $90 \%$ of music played on the broadcaster should be local. Such recognition of African languages and provisions for their speakers was not intended merely as a symbolic gesture, but as very much a strategy in deconstructing the historical injustices of racialized orderings and indexicalities connected to particular languages.

However, rather than offering the space for reconciliation, recognition and a more equal treatment of different languages, the notion of multilingualism upon which the provisions are built continues to reproduce language as a site of contestation. (cf. Stroud, 2001, 2009). This has been most apparent in the Higher Education sector where there has long been a need for radical linguistic and curriculum transformation (Kerfoot and Stroud, 2013), and where conflict over language has been most visible to date. Stellenbosch University has always seen itself as shouldering a special responsibility for nurturing Afrikaans. Despite the provisions ${ }^{2}$ it put in place to accommodate non-Afrikaans speaking students, the students's view was not enough had been done to address the issue of Afrikaans as a language of exclusion.

In 2015, and as part of the FeesMustFall protests for free, decolonial education that swept in waves across the country's universities, ${ }^{3}$ the question of language was made the centre-piece of the Open Stellenbosch Movement, a broad rank and file of student activists who called for wide ranging language reform at the university. As the protests grew in size and the debates congealed around the negotiating table, violence erupted as police tried to quell what the State perceived to be unwarranted and malicious destruction of property. This is the background to the specific moment of protest captured in the Luister documentary.

2. Most of these provisions used some model of bilingual teaching, such as simultaneous whispering translation, parallel classes etc.

3. 2015 saw wide spread student protests across the country against the lack of transformation of their institutions. At the University of Cape Town, protests started with student demands that the statue of Cecil Rhodes (the British colonialist) be removed from its place of prominence on the university steps overlooking the Cape Flats. This wing of the protest subsequently became the nation-wide call \#FeesMust Fall, and the demand for decolonized education. 


\section{The Luister (Listen) documentary}

We selected the Luister video for close analysis as it comprises a particular mainstay of the local Stellenbosch FeesMustFall movement. It received a substantial amount of coverage in both social media and conventional news coverage, its factual accuracy was vehemently denied by university authorities and charges of false and exaggerated claims were made against the producers of the film. It is as such a centre piece of controversy and highly revealing of the complexities and subtleties of the workings of colonial social logics in contemporary postcolonial societies (Povinelli, 2011; Stroud \& Guisemmo, 2017).

The 35-minute documentary was made in less than 17 days, and released 20th August 2015. Its makers (Dan Corder of Contraband, Cape Town and Open Stellenbosch) interviewed 32 students and one lecturer, specifically asking them to retell their experiences of exclusion, racism and discrimination at Stellenbosch University. The Luister documentary paints a stark and disturbing portrait of the daily trauma of the racialization of black Stellenbosch students. The violence against black bodies, and the vulnerability of being African, is narrated in uncomprising detail. We learn from those interviewed how their bodies are daily circumscribed by the White gaze, and defined by a "historical-racial-schema" (Gordon, 2015: 139). Despair and abandonment pervade the Luister students' recounts of their experiences of the university and the city of Stellenbosch where they feel that as if you do not belong to "this race (white) or don't speak Afrikaans" you become an object of victimization. The students are continually made aware of how their bodies - literally and symbolically - do not fit into the social-spatial tapestry of the university or the city. However, what is also striking across accounts from different students is frequent reference to the Afrikaans language as mediating racial discrimination; alongside harrowing stories of blatant, everyday racism, we also become cognizant of the subtle role of contemporary forms of linguistic coloniality in contributing to the racial quotidian.

Working with materials such as these places a particular ethical issue in sharp focus, namely the positionality of the researcher in mediating the voices of those with least cultural or linguistic capital. Our position is that many of the sharpened tools in our linguistic arsenal (e.g. critical (multimodal) discourse analysis) will invariably bring forth other meanings and other significances of what is said in the documentary. We have therefore chosen in this paper to follow a theoretically informed hermeneutic approach (cf. Gadamer, 1975) where our contribution is to work with the voices of the students in extending the reach and context of their complaints. Frantz Fanon (1967) had noted how inhabiting an imposed or enforced language by others results in the pain of 'existing absolutely for the Other'. As researchers we bring to the table a body of (albeit disparate) knowledge 
on how bodies and affect relate to language (from the writings of Frantz Fanon to the more recent emerging studies on semiotic landscapes, e.g Peck \& Stroud, 2015). Thus, our analyses suggest addendums and clarifications and interpretations of the student voices offered in constructive dialogue with the students. We therefore seek to enrich rather than deconstruct the narrative of students - looking for scripts and subscripts that tie the different stories together. We see this as one way of contributing to the construction of a decolonial archive.

In what follows, we hear the voices of the students detail the workings of the colonial construct of Afrikaans, ${ }^{4}$ a contruct that to a large extent is a linguistic product of the search for ethnic/racial purity, comprising processes of invisibilization and silencing of speakers; the erasure of multivocality; and sanitized accounts of the genesis of the language. We perceive traces of such processes and note how Fanon's sentiment is reenacted, lived and made audible in contemporary time through the bodies, sensibilities and voices of the black students in the Open Stellenbosch movement.

\section{Bodies and language 'out of lineage'}

In the following story, typical of many provided by different students in the documentary, "Black Male 5" recounts a distressing epidermal experience.

You know the colour of my skin in Stellenbosch is like a social burden. You walk around and as you, I mean just walking into spaces you know there is that stop, pause and stare where uhm people cannot believe that you would dare enter into this space.

The student notes elsewhere how he is 'blackened' and reflects on his awareness that the colour of his skin is a "social burden" in Stellenbosch. He is aware that there is a continual racial monitoring of his body, and that his body is inscribed social and spatial value, and made highly visible (and vulnerable), by the White gaze based on the colour of his skin.

The experiences of the Luister students are eerily resonant with Frantz Fanon's experiences. One of his key notions, offered in the essay 'Fact of Blackness' in Black Skin, White Masks, is that of 'racial epidermal schema'. At the opening of the

4. In this paper, we do not engage with the highly complex issues of multilingualism in African languages. South Africa has an admirable constitution that recognizes 11 official languages. However, as with all colonial contexts, the work of constructing these languages was a key technology of colonial subjugation (for example, see Makoni \& Pennycook, 2007; Harries, 2007; Plaatje, 1931). 
essay, he recounts how he is interpellated, while walking the streets of Paris, by a young Parisian child who shouts: "Look, a negro!". This hailing, which Fanon at first found amusing, alerted him to how his body - his general corporeal schema had in that moment been overtaken by a racial epidermal schema:

...my body was given back to me sprawled out, distorted, recolored, clad in mourning in that white winter day. The Negro is an animal, the Negro is bad, the Negro is mean, the Negro is ugly.

(Fanon 1967: 112)

Fanon's example of interpellation alerts us to the power of language to determine the parameters along which the body appears visible and is experienced subjectively. In another context, Fanon elaborates on the sense of psychic split that being forced to speak the colonial language (French) engenders in him - the feeling of "living absolutely for another". Much in the Luister documentary highlights the subtle and complex ways in which language 'produces' black bodies in white spaces for whites, forming the racialized experience of black students who suffer under the White obsession with epidermal differentiation.

The very specific complaints with regard to the multilingual provisions that the university offers elucidate one such complex of 'linguistic' racialization. ${ }^{5}$ In "Black female 4", a strong link is established between multilingualism, on the one hand, and physical discomfort and marginalization, on the other. The context is an engineering lecture in Afrikaans, and the trials experienced by the students in its translation.

So you listening to the lecturer and at the same time you also listening to the translator so you can't hear the translator has to whisper because the translator because they can't speak too loudly because we are in a lecture. So they whisper whisper and you can't exactly hear and you, I think the lecturer's voice overrides the translators voice. Also with the translation device they very delayed and sometime they don't use words like that aren't supposed to be, like they don't have the correct jargon because they not engineering students, they've never studied engineering, they studied language.

This example is one of a number of complaints the students put forward with regard to the multilingual provisions; interestingly, many of these complaints link language provisions to physical discomfort and being made to feel out of place. Reports abound about the physical discomfort of having to wear headphones; of

5. As noted earlier, Stellenbosch offers these provisions due to the university wanting to retain a prominent position for Afrikaans as a language as main instruction, simultaneously with opening its doors in the pursuit of post-apartheid racial equity to students who do not speak Afrikaans at a sufficient level of proficiency to be taught in it. 
how the poor sound quality masked the words of the lecturer; the asymmetry and lack of pacing between lecturer and interpreter, etc.

The situation reinforces for the student that the repertoires that are most accessible to them (African languages and English) are either invisibilized completely - as is the case for African languages or constructed as marginal or parenthetical to the event or place (English in an Afrikaans speaking lecture theatre). The process of translation, although ostensibly accommodation to, or recognition of, other repertoires, nevertheless functions to hammer home these construals.

When the language/repertoires are recognized, it is in conjunction with stigma - language as a trace or scar - as noted by Black Male 5. He frames his complaint by noting how a white student with a speech disability is given considerate respect, while, among black speakers,

as soon as for instance another fellow black person were to actually stand up and ask what they really want to know in class and then it happens that they don't have the correct accent, they don't roll their r's correctly, they don't ... pauses and so on and so forth, it becomes a whole big joke you know, within the class environment, and I absolutely abhor that. It's, it's disgusting...

These narratives testify to invisibilized and silenced (and ridiculed traces of African languages) - to a displaced or out-of-place speaker. But we can also read out of these commentaries how the displacement of languages is experienced physically as pain and discomfort, and emotionally as abhorrent. When we widen the narrative frame to consider the other stories the students tell, the complaints of bad translation services or linguistic stigma take on another significance, namely one of linguistic and corporeal displacement - Afrikaans is one dynamic in the construction of black bodies as constructed as marginal, exceptional, to the places they inhabit or move through. The conjunction of the participants' physical and emotional displacement, and the felt displacement of language is also found in the next vignette that highlights the constraints on mobility suffered by black bodies and languages.

During apartheid, black Africans were severely constrained as to where they could reside and where they could move, and how they could move (types of transport, etc). Loud echoes of this past can be heard in the narratives of the students. Black male 9, for example, recounts how he was stopped by security guards while returning to the residences after studying in the library. Immediately before him, a group of White students had enterd the campus gates, but

the security guards stopped me and asked me if I'm a student here and they asked to see my student card and I'm just, I literally said to them I'm like did you ask every single person that walked passed you here they like no, we're not trying to be difficult just show us your student card'. 
Black male 9 notes how "you have to, you, constantly, like, have to prove yourself as a black person in this space". He concludes his complaint by remarking on the blocking and friction he experiences when trying to 'import' a language not considered appropriate to the space;

I dunno, this the constant reminder that you don't belong here and that translates into class as well when the lecturer is speaking to you in Afrikaans. You wanna ask a question, if you ask it in English people sigh, people like why you speaking that language you know. It's just, I can't deal with the constant feeling of being like, of of of of feeling unwelcome all the time, in my own country.

This vignette again is one framed in terms of displacement, or being out of place and unwelcome ("you constantly have to validate who you are"). Just as physical mobility is constrained and requires validation, so is the use of languages other than Afrikaans constrained with respect to mobility and in need of validation.

\section{(Dis)Engtanglement/(dis)engagement}

In the following example, we again hear narrated a juxtaposition between bodies interpellated as black and language. In this case, the black body is 'exceptionalized' - made visible as 'black' - through the touch of White South Africans "tapping the woman that was working behind the counter on the head". Black male 4 again tells us how

We walked down at about twelve, one 'o clock er just to go get some Mc Donalds. This one guy was tapping the woman that was working behind the counter on the head (our italics) as if she was a dog and when we said that he should stop doing that he said no these are my friends. What I remember from that, because a lot has happened since then was almost seeing almost fear in the woman's but at the same time seeing that she had kind of been conditioned to that and that's when I knew that she didn't enjoy the kind of treatment. Uhm and also to think the kind of disrespect that this younger person has to come and treat an older person like this is something that he has been conditioned to because I know that those groups of students would never treat a white Afrikaans older person like that but if you black it almost you you treat them as almost their child.

Noticiable is how the 'head tapping' is a form of interpellation that only calls up the black body, but does so condescendingly in the figure of a childish, immature individual not worthy of respect. Positioning black bodies as servile, passive interlocutors of White patriarchy is an established colonial trope (cf. Stroud, 2007).

Further into the recount, we also note how the purported lack of Afrikaans from the repertoire of the black complainants is taken by the White assailants as grounds for ignoring the 'complaint' of the Black students. The students' lack of 
Afrikaans is called up by the offending actors as a way of justifying the exclusion of the students (and the attendant) from a shared moral order. The black students report how

we said you have to stop doing that, we don't like what you doing. They fought back instead of just apologising, they fought back. There was some swearing that went. Uhm an old friend of mine basically said we can't understand you and then they in Afrikaans responded if you don't speak Afrikaans you don't belong here (our italics)

Even though the event unfolded primarily around the physical infantilization of the black female attendant, the question of Afrikaans as a demarcator of belonging in Stellenbosch emerged at the height of the confrontation, and contributed to the vulnerability of the black students.

\section{Language in the fashioning of selves}

In all of the vignettes above, Afrikaans was invoked and juxtaposed - if only parenthetically or in passing - at the same time as the black students are interpellated around skin, constraints on mobility, exclusion from ethical interactional orders, and physical vulnerability. Although issues of Afrikaans are not always the core or central point of the narrative, mention of Afrikaans is nevertheless contiguous with talk on everyday racism. Afrikaans becomes the issue at points of conflict or high tension in the narrative; as the narrative reaches it 'peak', comments on Afrikaans are introduced as addendums or warrants. Even when Afrikaans is not the source of exclusion (as it was in Black Male 4 above), it is represented as something that arises out of exclusion, as one element in the set of categories of exclusion that can be talked about in the same breath as physically being made to feel out of place. Afrikaans in this sense is racially embodied in a very tangible sense.

The contiguity in the construction of language/Afrikaans as 'exclusion' and racialized physical violence is not coincidental. What the students are recounting bears a striking similarity to the context surrounding the birth of Afrikaans as a language emerging out of difficult encounters across difference. Language as a colonial project generally was part of the larger colonial program of subjugation: (i) a fundamentally political project - to civilize the natives - an important means for exercising control over people and their relationships (so control of languages need to be seen in a multilingual context of ordering and hierarchization); (ii) as a massive organization for labour and natural resource extraction, by transforming people into wage labourers, where the emerging rural workforce also tied to constructions of ethnic identity, race, gender (Fabian, 1986); (iii) a fundamental project of governmentality, comprising a broad range of disciplinary and regulatory 
practices - in the sense that, "colonialism inserted itself "into the very construction of its subjects, into their bodily routines and the essence of their selfhood" through numerous sites of control, institutional discourses and modes of surveillance (Stroud, 2007: 26 also quoting Comaroff, 1998: 329).

The events depicted in the student narrative bear an eerie resemblance to colonial uses of multilingualism as a tool of racial subjugation, with revoicing, exclusion, alienation, humiliation and shame remaining as powerful vectors in contemporary figurations of Afrikaans.

In the next section, we discuss alternative imaginaries of language and diversity, and a competing dynamics in the construal of Afrikaans that embody different forms of affect and different senses of self among speakers.

\section{Reconstructing multingualism, refiguring selves: The case of Afrikaaps}

In the Luister video, we saw how encounters through Afrikaans continue to replicate the history of exclusion associated with the language. Because of its creole origins (Early Dutch and a mixture of Portuguese, French and English, Malay, Khoi, San, Tamil), Afrikaans has been stringently policed with white Afrikaans practices designated as 'pure afrikaans or Standard Afrikaans, and offset against particular ideologically loaded named varieties closely tied to coloured identity ${ }^{6}$ that were seen as distorted speech, such as Kitchen Afrikaans, Coloured people's parlance or patois, Coloured language, Coloured Afrikaans, "Capey" or "Gammat-taal" (Small, 1972; Blignaut, 2014: 2; see Hendricks 2012 and Dyers 2008: 52; Alexander, 2012; Prah, 2012 for a debate on mainstreaming Afrikaans and the focus on its varieties; Hendricks, 2012).

It is this construct of Afrikaans that the Afrikaaps hiphopera takes issue with. Standard Afrikaans is dismantled in a performance that recaptures the voices of the excluded, re-immerses, and entangles those voices, and generates a representation of language associated to pride and confidence. This is accomplished through a critical reconstruction of the history of the language, the weaving of a very different idea of language as such, and the development of an alternative understanding of multingualism. The documentary, directed by Dylan Valley follows the temporal unfolding of Afrikaans: from its creole beginnings, its Arabic scripture to its latter-day standardization. Afrikaaps references a future, refigured Afrikaans,

6. Coloured was an ethnonym created by the apartheid government to refer to those of predominantly mixed race who were not easily classified as as either of the dominant categories, White or Black. Throughout apartheid it was a fraught category (Erasmus, 2001) and remains even more so today (e.g. Adhikari, 2006). 
sensitive to its roots in a 'stigmatized' Cape Flats Afrikaans spoken by the so-called coloured community in the Western Cape. The opera reflects the turbulent history of Afrikaans and its birth out of encounters and contests of voices across difference, providing an account of Afrikaans that challenges the tropes through which the language is conventionally understood and talked about. Instead of a language sculpted out of processes of racial subjugation, exclusion, and erasure (as experienced by the students of Stellenbosch), we find a representation of a language built on the inclusiveness of the voices of those historically subjugated, and the affirmation and visibility of entangled inter-racial histories. The pure and polished pedigree of Afrikaans' lineage from Dutch is replaced with the turbulent emergence of a 'hybrid' language, and the imprint of many voices is captured in the multivocality of the Afrikaaps performance. It is also a representation of language that recognizes language as affect-laden and embodied in corporeal relationships among speakers; whereas black bodies in the Luister video sit uncomfortably with Afrikaans, the bodies of Afrikaaps' speakers are deeply layered with knowledge and ownership of the language. The reimagination of Afrikaans as Afrikaaps simultaneously captures a different sense of multilingualism, one that structures relationships between speech practices and speakers in non-hierarchical terms and that acknowledges linguistic encounters as sites of struggle and vulnerability. The result, as we shall see, is a utopian sense of language that goes hand in glove with a euphoric, embodied and new sense of self.

\section{Opening up closures - rhizomatic lineage}

In contradistinction to Luister, where the imagined singularity and spatial exclusivity of Afrikaans was used to displace and racialize the other as other, the Afrikaaps documentary highlights explicitly the turbulent history of the language, and its genesis in the violent juxtaposition and clash of different voices (cf. Stroud, 2015). Rather than writing this turbulence out of history, the documentary structures its representation around this trope throughout - in its choice of voices and the personae chosen to comment, as well as in the themes and contents of the lyrics it presents. The late Neville Alexander, the iconic Director of the Program for Alternative Education in South Africa (PRASEA) ${ }^{7}$ and one of the country's

7. Throughout the documentary there is a shift between scenes from the Afrikaaps theatre performance at the Baxter theatre, spliced together with scenes of interviews with language activists such as Neville Alexander, expert Arabic historians' visits of the Afrikaaps theatre group to a school and footage of the school children at the Baxter theatre, and archival footage of the forced removals and Cape Coon Carnival. 
most influential language activists during his lifetime, remarks explicitly on the confrontational beginnings of Afrikaans,

As die Kho, die San, en die Slawe veral nie gedwing was om Hollands of Nederlands te leer nie of te praat nie, dan sou die taal Afrikaans eintlik nie onstaan het nie.

If the Khoi, the San and the slaves were not forced to learn (our italics) Dutch then Afrikaans would not have existed

The history of Afrikaans as one of disruption of 'lineage', and the outcome of interruption and juxtaposition, is also captured by Catherine, the producer, in her introductory comment

The purpose of the show is that we deal with the history of Afrikaans and it goes on into the 50s where people are then not only dispossessed of their language but they are also dispossessed of their homes and in that process their identities are fractured.

In one of the scenes recorded at the Baxter theatre, Monox, one of the participants in the opera, paints the rhizomatic birth of Afrikaans in this stage performance in the following words;

\section{Monox:}

1. Ek is 'n number met'n storie ou pel

I'm a number with a story old pal

2. Van hoe my mense hulle feelings en geheime vertel

About how people talk about their feelings and secrets

3. Ek was gebore daar in Europe met'n ander taal

I was born in Europe with a different language

4. Maar innie Kaap was ek gekap met 'n creole style

But in Cape Town I was produced with a creole style

5. Ek is ook baie gesing met 'n ghoema sang

I've been sung a lot with a ghoema song

6. Ek vat jou hand Zanzibar en Dar Es Salaam

I take your hand from Zanzibar to Dar Es Salaam

7. Dutch Sailor Boy

8. wat sing jy daar?

What are you singing?

9. Sal jy mind as ek vir jou 'n klein vragie vra

Do you mind if I ask you a question

10. Sing jou song gou weer, en dan 'n nogger keer

Sing your song again, and then again

11. Nou kan ek mos al my broese dai song leer

Now I can teach all my brothers that song

12. Oor'n uur of twee sal ons dai number ken

Over an hour or two well know that song 
13. Met 'n smile sing ons hom now and then

14. We'll sing that song

Monox sings of the origins of Afrikaans in migration and creole entanglements, a language with roots stretching from Zanzibar and Dar Es Salaam, with important milestones celebrated in the ghoema song. The ghoema harks back to the musical culture of the 17th Century Malay Slaves, and was a celebration of their being granted freedom in 1834; to celebrate their freedom, they would march in groups in central Cape Town every year. Monox draws attention to how one effect of cycles of disruption, re-formation, and juxtaposition is that no single group of speakers can lay claim to ownership or authenticity of the language, as successive and layered encounters and entanglements of speakers have historically contributed to the rhizomatic character of Afrikaans today.

\section{Entanglements}

Turbulence, juxtaposition and interruption also give rise to a multivocality of voices, which is represented as part of the genesis of Afrikaans through a gallery of personae. In the opening 10 minutes of the documentary, the viewer is introduced to the main protagonists whose different histories personify the many roots of Kaaps.

The multivocal imaginary of Afrikaans emerges out of the entanglement of circumstances and people, as something that gives voice to, articulates, a diversity of life-styles and life-forms. Again, this is very different to what we see in the Luister video. The documentary captures this with Emil XY?'s staged performance at the Baxter theatre, perhaps one of the best known rappers in South Africa, highlighting the complexities and extent of entanglements in the following verse from the scene production

\section{Emile YX?:}

1. Ek is dai dammies player I'm that dominoes player

2. Kennetjie en als doels Kennetjie en other games

3. Ek was n ANC supporter I was an ANC supporter

4. En nou se ek sy Ma se...

Now I say they're Mother...

5. Ek is dai Boesman taal tolke I'm that Bushman language translator

6. Corner Broker 


\section{Gooi nee jou tol}

Throw down your spinning tol toy

8. Want hiesa gaan djy stoeka

Cause here you'll have to play

9. Ek is dai moss murderer

I'm that mass murderer

10. Tyre Burner

11. Minimal wage, sub-economic earner

12. Ek's dai dokter, lawyer, politician

I'm that doctor, lawyer, politician

13. Innie ghetto

In the ghetto

14. Wait a minute

15. Most of them moved out

16. Awe!

Cool!

In the above, Emile performs his lyrics indexing local cultural practices and performances. He rhymes about favourite past-times and games: playing dominoes and little chin (kennetjie), the latter a children's game where an opponent hits a short stick with a longer stick in the air to be caught by fielders. In lines 2 and 3, the performer suggests that he was once an ANC supporter but now he chides them. He further rhymes that he sees himself as a translator of Bushman language (possibly Khoi or San languages), and suggests that that when people encounter him what they will expect is that he is able to stylize his language like a Corner Broker (line 6). ${ }^{8}$ Furthermore, the large portion of his lyrics reference the class struggle "innie ghetto", the various stereotypical middle class economic roles assigned to Kaaps speakers and the pains of upward economic mobility working class Coloureds experience when docters, lawyers and politicians move out.

As with the Luister video, there is an embodiment of language and linguistically mediated identities that manifest not as narrow racializations, but rather as a corporeal kaleidoscope of 'possibilities'. The significance of Emile YX?'s verse lies in his breaking down of identity stereotypes by merging and mixing different personae in the body and voice of the same speaker. He is using Afrikaans to mediate an embodiment of diversity - ethnic, racial, social class - in contradistinction to how the language is usually represented as located in the body of the White, middle-class, 'Afrikaner' only.

Thus, rather than promoting a story of an emerging and focused linguistic standard, and far from fixing the language to a specific time, place or embodied

8. A Corner Broker, traditionally defined, is an informal trader who sells fruit and other affordable products on the corner of streets in the townships of Cape Town. 
identity, the various characters that personify Kaaps celebrate a broad span of nonstandard ways of talking, made up of a wide range of registers (criminal argots, children's rhymes, and poetic adoptions of Khoisan languages, playful exercise of clicks), forms of play and musical gigs, dance moves and comic forms and rhythms. We witness a highly chronotopical rendition of the 'language', fluid and scripted for and by the different individual histories, repertoires and biographies. Afrikaans becomes a reservoir for a pool of personae. Rather than a singular, determinate authenticity with an immaculate and unsoiled pedigree, the representation of Afrikaans as heteroglossic and polyphonic gives an 'authenticity of historical encounter' to the language. Whereas 'ownership' of Afrikaans is not disrupted in the Luister documentary, it is fiercely challenged in the Afrikaaps video through the many voices that comprise it.

\section{Knowing a language bodily}

In Luister, Afrikaans is excluded from incorporation in the black body. In the Afrikaaps documentary, on the other hand, as we saw above with the verse from Emile YX?, the sense of language that emerges is deeply embodied - there is a physical sense of well-being in Kaaps, expressed in dance and traditional movement. Afrikaans is intimately represented as Afrikaaps corporeality.

In the following plates, learners are demonstrating their skill in an age-old genre of dance performance - Ghoema - one which intimately glues together kaaps, body movement and facial expression into a chronotopical and embodied representation of Afrikaans that reaches back to, and indexes a historical reenactment of Ghoema dance.

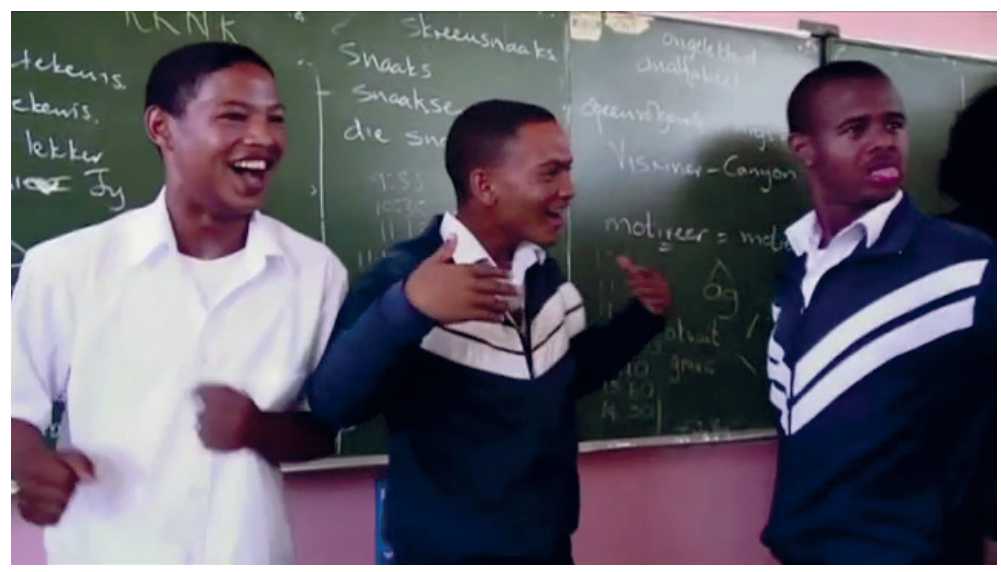

Screen Grab School Children at Lavender Hill Performing Ghoema 


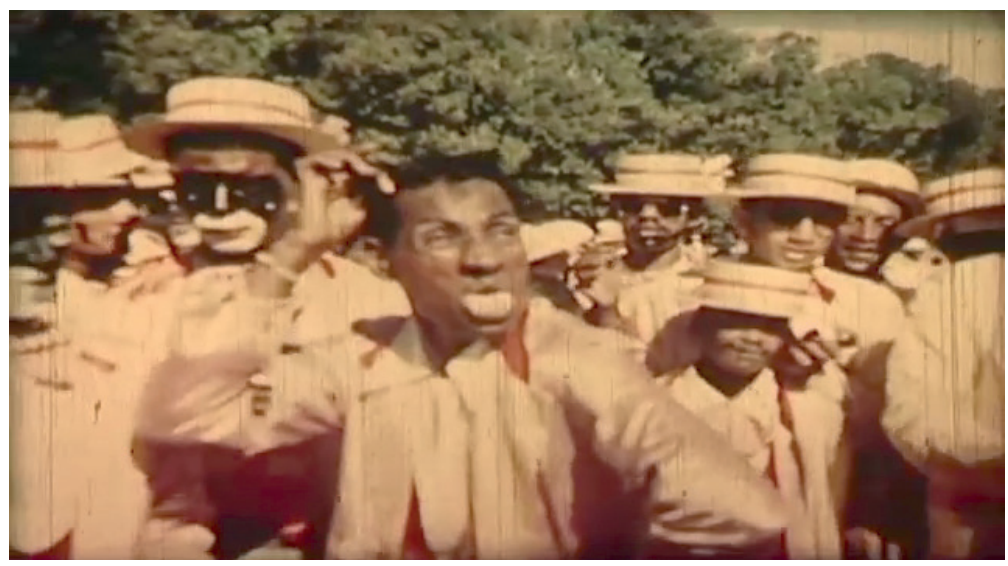

Screen Grab Archival material about Cape Coons Performing Ghoema

The plates show three pupils dancing to the rhythm of a banjo. These are shots from the documentary capturing the moment when EmilXY? and colleagues brought clips of the stage performance to the school to elicit talk around Afrikaaps. The pupil on the left swings his arms, the one in the middle slaps his chest and the pupil on the right acts a fool by making funny and weird faces. This is all in the spirit of Ghoema. The pupils through their gyrations enact the liberated body politic of the Malay slaves, simultaneously celebrating the more contemporary Cape Coon dance culture. An interesting take in the documentary, visible in the screen grabs, is that the backdrop to the presentation is the Afrikaans lesson on the board behind the students teaching Afrikaans comparatives.

Dance, song, gesticulation, mimicry allow for the embedding of current practices and their speakers in a multidimensional historical narrative on the origins, continuities and ruptures of language. This reclaiming of an authoritative voice, unconventionally articulated, offers an appreciation of Afrikaans that goes well beyond standard accounts.

In Luister, the students spoke of their existential pain and despair. In the Afrikaaps documentary, we note instead an ecstasy of liberation, dignity, autonomy, agency, and inclusivity in Afrikaans, as the one voice after the other tells its story of Afrikaans in the documentary, morphing Afrikaans into a vision of Afrikaaps. The Afrikaaps documentary celebrates a linguistic reconnect of self and language through Afrikaaps, where together with the emergence of 'Afrikaaps', selves are refigured and a new, vocal, political voice emerges that is reclaiming ways of speaking deeply entwined with alternative thinking of what it means to be a speaker of Afrikaans. We hear the voices of three learners who, after watching the play at the Baxter theatre in Cape Town, briefly reflect on how it has overturned 
some of their preconceived ideas of not just the language they speak, but also their sense of self.

\section{Multiple School Pupils:}

Pupil 1: I feel "Uh!"

It was mind blowing

Pupil 2: Ek het noot gewiet van my voorvaders

Praat deur my nie.

I never thought that my forefathers speaks through me.

Pupil 3: Ek gat nie meer soe skaam wees om te praat soes ek praat nie.

Ek gat nie weer compromise op die taal vir ander mense nie.

I will not be shy anymore to speak the way I speak

I will not compromise anymore on the use of my language because of other people

From initially expressing strong surprise and bewilderment, the first two pupil's comments reveal how they see themselves and their forefathers differently through their 'discovery' of Afrikaaps. The third pupil goes one step further by stating she will never shy away from the way she speaks or compromise on her language for other people who may think she should do otherwise.

\section{Discussion: Hope and despair}

In the above, we have presented two case studies with two distinct understandings of multilingualism that each has very different implications with respect to the how racialized selves are fashioned. The Luister video highlights a construct of multilingualism typical of a colonial governmentality, one that contributes to the formation of racialized and vulnerable bodies, through the erasure and hierarchization of languages. In many respects, the Stellenbosch students remain caught up in the shallows and rocks of global flows of racialization semiotics.

The documentary Afrikaaps, on the other hand, opens up a different vista on multilingualism as a site for renegotiating what a language is and what it may mean (Stroud, 2001). It is fundamentally about reclaiming ownership and authority over Afrikaans. Afrikaaps gestures towards a way of doing and thinking language 'otherwise'. It is about an 'ontological refashioning' (Soudien, 2014), a fundamental shift in, what it means to be an Afrikaans speaker through engaging in practices of language that interrupt standard, received and conventional ideas of Afrikaans; and that open up (anarchistically) to a repertoire of multiple registers and varieties, linguistic or multimodal/transmodal. It is about realizing the potential of these alternative figurings of language to shift power relations, to relegitimize voice and to insert oneself into a space of dignity. The processes at work here document acts of linguistic citizenship. Linguistic citizenship (Stroud, 2001, 2009) is the event/moment 
when representing languages in particular ways becomes crucial to, becomes the very dynamic through which, acts of agency and participation, and reconceptualizations of self in matrices of power occur. We find instances of linguistic citizenship in many peripheral contexts where there is a groundswell of resistance to centrist and neoliberal/colonial replications of languages and selves. Such re-appropriations of language by communities of speakers on the periphery often involve (and evolve) understandings of language, authenticity and ownership that diverge significantly from more institutionalized discourses on language (e.g. Stroud, 2001).

However, what is of interest in both cases is how 'language' as a labeled and lived experience is entwined with corporeal relations and constructs of Self. When the Luister participants talk about pain and exclusion, or when the Afrikaaps participants talk about Afrikaans as Afrikaaps, we get a glimpse of a new possible register for talking about language and how language emerge, uneasily or easily, out of encounters across difference, at the same time as bodies and selves become. It is this assemblage of bodies, language and affect that places language squarely within the real, material world with real consequences for speakers. Viewing language as a formative dynamic in encounters promises to widen our understanding of the complexities and contextualities of the notion of multilingualism itself. Above all, it focuses our attention on multilingualism as a site where language and self can be refashioned through practical engagement with how encounters are semiotized. In Afrikaaps, we are witnessing a 'utopian' concept of language take form momentarily.

Ernst Bloch (1985) has written extensively on the idea of 'utopia.' His' use of the concept of utopia does not carry the same meaning as the word utopia introduced by Thomas Moore. It is not an ideal, imagined, abstract state, a somewhere or something which is neither here, there nor now. The most important concept with which to grasp Bloch's understanding of the utopian is the not-yet. ${ }^{9}$ It refers to a better way of living that is foreshadowed in the present (as it has also has been in the past). Because the world is unfinished, ever changing, there are a number of waýs and forms in which it can become, and those forms are present in alterntaice ways of thinking, living, and talking now as they have been historically (Anderson, 2002). Anderson defines the utopic as "plural goods and betters that are not-yet but immanent to life and therefore have disruptive, interrogative qualities". Furthermore, the mark of a utopic moment is that it leaves an affective signature: (Anderson 2002: 694) - the 'feeling', the sensibility of being in a utopian state and under

9. Bloch talks of the not-yet conscious in dialogue with Freud, as an anticipatory conscious, the pre-conscious, the day-dream - a prospective rather than retrospective - thought that struggles to surface rather than remain buried. The not-yet become refers to the understanding of the present through the uneasy presence or absence of the future. 
what conditions this happens: "The answer to the question of what is utopia must revolve around the rare spark or glimmer of hopefulness".

The performance of Afrikaaps captures the utopic experience of thinking language otherwise. Afrikaans as foregrounded in Afrikaaps is not the conventional, normative, taught Afrikaans, but the potential for Afrikaans to be something else. It is a potential that is layered already into, and in some sense prefigured in the language. It is a 'pre-dawning' of an idea of (language and society) that is 'NOT-YET but immanent to a world that contains "something that has not realized itself" (Bloch, 1985: 221). Afrikaaps is disruptive and interrogative. At the same time, Afrikaaps impels a euphoric awareness in those who speak it that things could be different and selves can be refashioned. We see utopic moments in how the participants in the documentary are rethinking the relationships of power underlying particular practices and understandings of language(s) - such as who may decide what a language is, or which speakers count as legitimate. (They are also laying bare the disruption and violence - the darker side of a politics of institutionalized linguistic recognition - to which they have been subjected and silenced throughout history). The documentary presents a picture of Afrikaans/Kaaps "attuned to the implications of multitude of identities, subject positions, and positions of interest" (Stroud, 2009: 213), and reframes "semiotic practices of citizenship away from a totalizing sense of language" (ibid).

It is here that Bloch's notion of utopia can provide a way for thinking about the role of multilingualism as a script for crafting the 'new human mutuality' that Mbembe spoke about in a transforming South Africa. Multilingualism - the semiotization of encounters - as a utopian construct can inspire the writing of competing futures that are not drawn out of the tendencies, trajectories and normative understandings of the past, but that are nevertheless present in these moments as disruptive alternatives. In particular, a utopian construct of multilingualism draws attention to how vulnerabilities are engaged and created in formations of linguistic regimes. This in itself could comprise an important first ethical step in the contribution applied linguistics can make to a rejuvenated human mutuality.

\section{References}

Adhikhari, M. (2005). Not white enough, not black enough: racial identity in the South African coloured community. Athens, OH: Ohio University Press.

Adhikhari, M. (2006). Hope, fear, shame and frustration: Continuity and change in the expression of coloured identity in white supremacist South Africa, 1910-1994. Journal of South Africa Studies, 3(3), 467-487. doi:10.1080/03057070600829542

Alcoff, L. M. (2007). Epistemologies of ignorance: three types. In S. Sullivan \& N. Tuana (Eds.), Race and epistemologies of ignorance (pp. 39-58). Albany, NY: State University of New York Press. 
Alim, H. S., Rickford, J., \& Ball, A. (Eds.). 2016. Raciolinguistics: How language shapes our ideas of race. Oxford: Oxford University Press.

Alexander, N. (2013). Thoughts on the new South Africa. Johannesburg: Jacana Press.

Anderson, B. (2002). Principle of hope: Recording music listening practices and the immanence of of utopia. Geografiska Annaler, 84B (3-4): 211-227. doi:10.1111/1468-0467.00125

Battersby, J. (2003). "Sometimes it feels like I'm not black enough": Recast(e)ing coloured through South African hip-hop as a postcolonial Text. In H. Wasserman \& S. Jacobs (Eds.), Shifting selves: Post-spartheid essays on mass media, culture and identity (pp. 109-129). Cape Town: Kwela Books.

Blignaut, J. (2014). Ondersoek na die taalgebruik ni Son as verteenwoordigend van Kaapse Afrikaans. Unpublished MA thesis, Stellenbosch University.

Bloch, E. (1985). The principle of hope. Oxford: Blackwell.

Comaroff, John L. (1998). Reflections on the colonial state in South Africa and elsewhere: factions, fragments, facts and fictions. Social Identities, 4(3), 321-61.

Comaroff, J., \& Comaroff, J. (2012). Theory from the south: Or, how Euro-America is evolving toward Africa. New York, NY: Paradigm Publishers.

Chun, E., \& Lo, A. (2016). Language and racialization. In N. Bonvillain (Ed.), Routledge handbook of linguistic anthropology (pp. 220-233). New York, NY: Taylor and Francis.

Davids, A. (2011). The Afrikaans of the Cape Muslims from 1815 to 1915. Pretoria: Protea Book House.

De Sousa Santos, B. (2009). A non-occidental? Learned ignorance and ecology of knowledge. Theory, Culture and Society, 26(7-8), 103-125. doi:10.1177/0263276409348079

Dyers, C. (2008). Language shift or maintenance? Factors determining the use of Afrikaans among some township youth in South Africa. Stellenbosch Papers in Linguistics, 38, $49-72$.

Eze, C. E. (2008). Language and time in post-colonial experience. Research in African Literatures, 39(1), 24-47. doi:10.2979/RAL.2008.39.1.24

Erasmus, Z. (Ed.). (2001). Coloured by history, shaped by place: New perspectives on coloured identities in Cape Town. Cape Town: Kwela Books.

Falkoff, N. (2015). The end of whiteness. Johannesburg: Jacana.

Fabian, J. (1986). Language and colonial power: The appropraition of Swahili in the former Belgian Congo, 1880-1938. Berkeley, CA: University of California Press.

Fanon, F. (1967). Black skin, white masks. New York, NY: Grove Press.

Gadamer, H.G. (1975). Truth and method. London: Continuum.

Giliomee, H. (2005). The Afrikaners: A biography. Cape Town: Tafelberg Publishers.

Gordon, L. (2015). What Fanon said? A philosophical introduction to his life and thought. USA: Fordham University Press.

Harries, Patrick. (2007). Butterflies and Barbarians: Swiss Missionaries and Systems of knowledge in South-East Africa. Oxford: James Currey Press.

Haupt, A. (1995). Rap and the articulation of resistance: An exploration of subversive cultural production during the early 90s, with particular reference to Prophets of da City. Unpublished MA Mini-thesis, University of the Western Cape.

Haupt, A. (1996). Stifled noise in the South African music box: Prophets of Da City and the struggle for a public space. South African Theatre Journal, 10(2), 51-61. doi:10.1080/10137548.1996.9688177

Haupt, A. (2001). Black thing: Hip-hop nationalism, 'race' and gender in Prophets of da City and Brasse vannie Kaap. In Z. Erasmus (Ed.), Coloured by history, shaped by place: New perspectives on coloured identities in Cape Town (pp. 172-194]). Cape Town: Kwela Books. 
Hendricks, F. (2012). Iluminating the neglected: A view on Adam Small's literary integration of Kaaps. Tydskrif vir Letterkunde, 49(1), 95-114.

Isin, E. F. (2009). Citizenship in flux: The figure of the activist citizen. Subjectivity, 29, 367-388. doi: $10.1057 /$ sub.2009.25

Kerfoot, C., \& Stroud, C. (2013). Towards rethinking multilingualism and language policy for academic literacies. Linguistics and Education, 24, 396-405.

Kerfoot, C., \& Hyltenstam, K. (Eds.). (2017). Entangled discourses: South-north orders of visibility. London: Routledge.

Makoni, S., \& Pennycook, A. (Eds.). (2007). Disinventing and reconstituting languages. Clevedon: Multilingual Matters.

Mbembe, A. (2015). Decolonizing knowledge and the question of the archive. Johannesburg: WISER, Wits University.

Mbembe, A. (2016). Africa in theory. In B. Goldstone \& J. Obarrio (Eds.), African futures: Essays on crisis, emergence, and possibility. Chicago, IL: University of Chicago Press.

Mesthrie, R. (2008). "I've been speaking Tsotsitaal all my life without knowing it": Towards a unified account of tsotsitaals in South Africa. In M. Meyerhoff \& N. Nagy (Eds.), Social lives in language (pp. 95-109). Amsterdam: John Benjamins.

Plaatje, S. (1973). Native life in South Africa: Before and since the European War and the Boer Rebellion. London : King.

Povinelli, E. (2011). Economies of Abandonment: Social Belonging and Endurance in Late Liberalism. Durham: Duke University Press.

Small, A. (1972). Adam Small in gesprek met Ronnie Belcher. Gesprekke met Skrywers 2 (pp. 93-105). Cape Town: Tafelberg Uitgewers.

Small, A. (1987). Kitaar my kruis, derde, hersiene uitgawe. Pretoria: HAUM-Literêr.

Soudien, C. (2014). Bodies of language and languages of bodies: South African puzzles and opportunities. In M. Prinsloo \& C. Stroud (Eds.), Educating for language and literacy diversity: Mobile selves (pp. 206-215). London: Pallgrave.

Stroud, C., \& Guissemo, M. (2015). Linguistic messianism. Multilingual Margins 2(2): 7-21.

Stroud, C. (2001). African Mother Tongue programs and the politics of language: Linguistic citizenship versus linguistic human rights. Journal of Multilingual and Multicultural Development 22(4): 339-355. doi:10.1080/01434630108666440

Stroud, C. (2004). The performativity of code-switching. International Journal of Bilingualism, 8(2), 145-166. doi:10.1177/13670069040080020301

Stroud, C. (2007). Bilingualism: colonialism and postcolonialism. In M. Heller (Ed.), Bilingualism: A Social Approach (pp. 25-49). Houndmills: Palgrave MacMillan.

Stroud, C. (2009). A postliberal critique of language rights: Toward a politics of language for a linguistics of contact. In J. E. Petrovic (Ed.), International perspectives on bilingual education: Policy, practice and controversy (pp. 191-218). Charlotte, NC: Information Age Publishing.

Stroud, C. (2015). Afterword: Turbulent deflections. In C. Stroud \& M. Prinsloo (Eds.), Language, Literacy and Diversity: Moving Words. London: Routledge.

Walker, M. (2005). Race is nowhere and race is everywhere: Narratives from black and white South African university students in post-apartheid South Africa. British Journal of Sociology of Education, 26(1), 41-54. doi:10.1080/0142569042000292707 